\title{
Formation of Alkanes by Aerobic Carbon-Carbon Bond Coupling Reactions Catalyzed by a Phosphovanadomolybdic Acid
}

\author{
Miriam Somekh, ${ }^{\dagger}$ Hagai Cohen, ${ }^{\dagger}$ Yael Diskin-Posner, ${ }^{\ddagger}$ Linda J. W. Shimon, ${ }^{\ddagger}$ Raanan Carmieli, ${ }^{\ddagger}$ \\ Jeffrey N. Rosenberg, ${ }^{\dagger, \S}$ and Ronny Neumann*, ${ }^{*}+$ (0) \\ ${ }^{\dagger}$ Department of Organic Chemistry, Weizmann Institute of Science, Rehovot 76100, Israel \\ ${ }^{\ddagger}$ Department for Chemical Research Support, Weizmann Institute of Science, Rehovot 76100, Israel
}

\section{Supporting Information}

ABSTRACT: The valorization of alkanes is possible via carboncarbon coupling reactions. A series of dialkyl cobalt complexes $\left[\left(\mathrm{RCH}_{2}\right)_{2} \mathrm{Co}^{\mathrm{III}}(\mathrm{bpy})_{2}\right] \mathrm{ClO}_{4}(\mathrm{R}=\mathrm{H}, \mathrm{Me}, \mathrm{Et}$, and $\mathrm{Ph})$ were reacted with the $\mathrm{H}_{5} \mathrm{PV}_{2} \mathrm{Mo}_{10} \mathrm{O}_{40}$ polyoxometalate as a catalyst, leading to a selective oxidative carbon-carbon bond coupling reaction. The
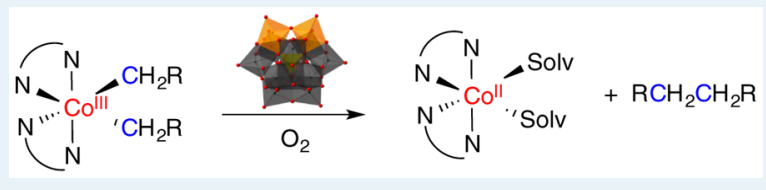
reaction is initiated by electron transfer from $\left[\left(\mathrm{RCH}_{2}\right)_{2} \mathrm{Co}^{\mathrm{III}}(\mathrm{bpy})_{2}\right]^{+}$

to $\mathrm{H}_{5} \mathrm{PV}_{2}{ }_{2} \mathrm{Mo}_{10} \mathrm{O}_{40}$ to yield an intermediate $\left[\left(\mathrm{RCH}_{2}\right)_{2} \mathrm{Co}^{\mathrm{IV}}(\text { bpy })_{2}\right]^{2+}-\mathrm{H}_{5} \mathrm{PV}^{\mathrm{IV}} \mathrm{V}^{\mathrm{V}} \mathrm{Mo}_{10} \mathrm{O}_{40}$, as identified by a combination of EPR and $\mathrm{X}$-ray photoelectron spectroscopy experiments. The reaction is catalytic with $\mathrm{O}_{2}$ as terminal oxidant representing an aerobic $\mathrm{C}-\mathrm{C}$ bond coupling reaction.

KEYWORDS: aerobic oxidation, $C-C$ bond coupling, polyoxometalate, XPS, electron transfer

\section{INTRODUCTION}

Oxidative $\mathrm{sp}^{3}-\mathrm{sp}^{3} \mathrm{C}-\mathrm{C}$ bond coupling reactions of metaldialkyl compounds through an oxidative reductive elimination pathway is quite well-known. For example, early work by Kochi and colleagues showed that thermolysis of $\mathrm{Et}_{2} \mathrm{Fe}(\mathrm{bpy})_{2}$ yielded ethene and ethane, products of $\beta$-hydrogen elimination; however, a two-electron oxidation process led to selective reductive elimination and formation of $n$-butane only. ${ }^{1}$ More recent research has been focused on square planar $\mathrm{Pd}(\mathrm{II})$ compounds where reactions proceed via higher valent $\mathrm{Pd}(\mathrm{III})$ or Pd(IV) intermediates. ${ }^{2}$ Such reactions have much present relevance also in the context of valorization of light alkanes, especially methane. Recently, there have been some reports on similar intermolecular $\mathrm{C}-\mathrm{C}$ bond coupling reactions from both $\mathrm{Pd}(\mathrm{II})$ and $\mathrm{Ni}(\mathrm{II})$ square planar precursors. ${ }^{3}$ Generally speaking, oxidation at the metal center has been achieved by using both one- and two-electron stoichiometric oxidants, often in excess. The use of ferrocenium cations, ${ }^{4} \mathrm{Ag}^{+}, 5$ benzoquinone, ${ }^{6}$ and pyridinium compounds, ${ }^{7}$ among others, is notable.

Surprisingly, the use of $\mathrm{O}_{2}$ as terminal oxidant has not been shown for the oxidative coupling reactions mentioned above. To facilitate such a transformation, a one- or two-electron oxidant to the metal-dialkyl species that could be then recovered by reoxidation with $\mathrm{O}_{2}$ would be very advantageous toward an aerobic catalytic transformation. Indeed, it has been shown in the past that phosphovanadomolybdates of the $\alpha$ Keggin structure such as $\mathrm{H}_{5} \mathrm{PV}_{2} \mathrm{Mo}_{10} \mathrm{O}_{40}$ are excellent electrontransfer oxidants of many substrate types that upon reduction by one or two electrons are quite easily reoxidized by $\mathrm{O}_{2}{ }^{8} \mathrm{It}$ should be specifically noted that tetra-alkyltin compounds also can be activated and aerobically oxidized with $\mathrm{H}_{5} \mathrm{PV}_{2} \mathrm{Mo}_{10} \mathrm{O}_{40}$, but in that case, oxygen insertion into the metal-carbon bond occurs to yield an alcohol as the product. ${ }^{9}$ In the research presented in this paper, we demonstrate such an aerobic oxidative $\mathrm{C}-\mathrm{C}$ bond coupling reaction with dialkyl cobalt(III) substrates (Scheme 1).

Scheme 1. Aerobic Oxidative $\mathrm{C}-\mathrm{C}$ Bond Formation in Dialkylcobalt(III) Compounds Catalyzed by $\mathrm{H}_{5} \mathrm{PV}_{2} \mathrm{Mo}_{10} \mathrm{O}_{40}$

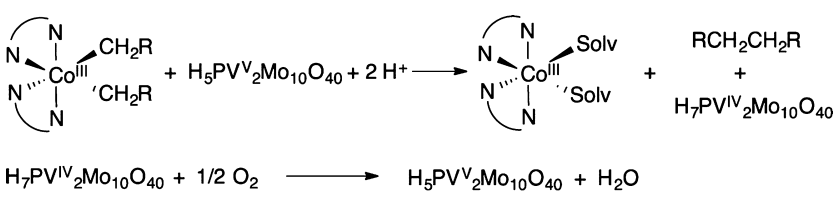

\section{RESULTS AND DISCUSSION}

A series of dialkyl cobalt complexes $\left[\left(\mathrm{RCH}_{2}\right)_{2} \mathrm{Co}^{\mathrm{III}}(\mathrm{bpy})_{2}\right] \mathrm{ClO}_{4}$ where $\mathrm{R}=\mathrm{H}(\mathbf{1 a}), \mathrm{CH}_{3}(\mathbf{l b}), \mathrm{CH}_{3} \mathrm{CH}_{2}$ (1) $), \mathrm{Ph}(\mathbf{1 d})$, and for cyclic- $\mathrm{CH}_{2} \mathrm{CH}_{2} \mathrm{CH}_{2} \mathrm{CH}_{2}$ (1e) was synthesized by adaptation of a literature method that involves the in situ reductive alkylation of a $\mathrm{Co}$ (II) salt in the presence of 2,2'-bipyridine, $\mathrm{NaBH}_{4}$ and the appropriate alkyl halide. ${ }^{10}$ The red complexes that were obtained were diamagnetic. Crystal structures were obtained for 1c,d (Figure 1) and 1e (Figure S11).

The crystal structures revealed the expected six-coordinate regular octahedral complex with the alkyl moieties in the $\alpha$-cis positions. We were unable to crystallize complexes $\mathbf{1 a - b}$; however, they were unequivocally identified by their NMR spectra (see the Supporting Information).

Received: February 12, 2017

Revised: March 8, 2017

Published: March 14, 2017 


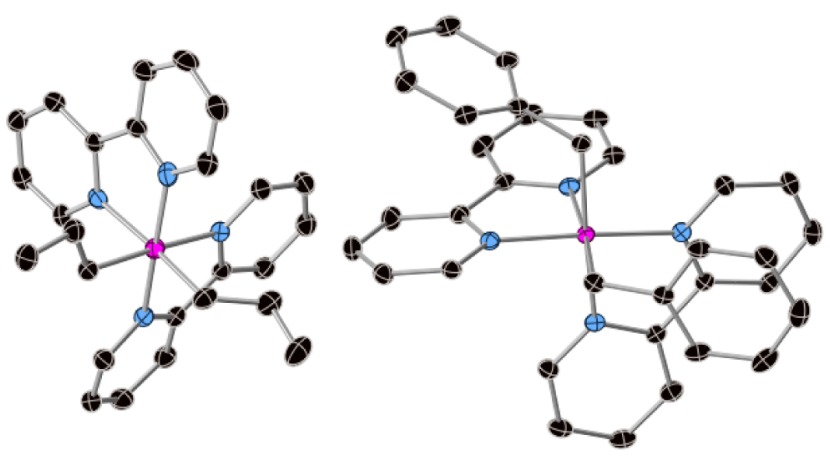

Figure 1. ORTEP drawing (50\% probability) of $1 \mathrm{c}$ (left) and 1d (right). Co, magenta; C, black; and N, blue. Hydrogen atoms and the $\mathrm{ClO}_{4}$ anion are not shown.

After preparation of $\mathbf{1 a}-\mathbf{e}$, they were each reacted with an equivalent amount of $\mathrm{H}_{5} \mathrm{PV}_{2} \mathrm{Mo}_{10} \mathrm{O}_{40}$ as oxidant under $\mathrm{Ar}$. Thus, $30 \mu \mathrm{mol}$ of 1 and $30 \mu \mathrm{mol}$ of $\mathrm{H}_{5} \mathrm{PV}_{2} \mathrm{Mo}_{10} \mathrm{O}_{40}$ in $6 \mathrm{~mL}$ of $n$-butyronitrile were reacted at RT. Immediately, a blue precipitate of the signature heteropoly blue compound was formed signifying that the polyoxometalate was instantaneously reduced. Analysis of the reaction mixture at this point showed no significant formation of product, indicating that the precipitate is a reaction intermediate (see below). Subsequent heating of the solution at $50{ }^{\circ} \mathrm{C}$ for $3 \mathrm{~h}$ revealed the quantitative formation of ethane, $n$-butane, $n$-hexane, bibenzyl, and cyclobutane for $\mathbf{1 a}-\mathbf{e}$, respectively. No oxygen transfer from the polyoxometalate by an ET-OT mechanism ${ }^{8}$ to obtain an oxygenated product such as $\mathrm{RCH}_{2} \mathrm{OH}$ was observed, as occurred with $\mathrm{Sn}(\mathrm{alkyl})_{4}$ substrates. ${ }^{9}$ Rather, the results point to a highly selective head-to-head oxidative carbon-carbon coupling with no formation of byproducts. For example, from 1c, no propane, propene, acetone, or other hexane isomers were formed. A control experiment without $\mathrm{H}_{5} \mathrm{PV}_{2} \mathrm{Mo}_{10} \mathrm{O}_{40}$ showed that 1 was stable under the reaction conditions. Only upon heating to $220{ }^{\circ} \mathrm{C}$ was a mixture of products formed. Similar stoichiometric reactions of $\mathbf{1}$ and $\mathrm{H}_{5} \mathrm{PV}_{2} \mathrm{Mo}_{10} \mathrm{O}_{40}$ under 1.5 bar $\mathrm{O}_{2}$ also yielded only the $\mathrm{C}-\mathrm{C}$ coupling products except for $1 \mathbf{d}(\mathrm{R}=\mathrm{Ph})$ where both benzaldehyde $(83 \%)$ and bibenzyl (17\%) were formed in a quantitative reaction. Since oxygen transfer from the polyoxometalate was not observed for $1 \mathbf{a}-\mathbf{e}$, one can conclude that for $\mathbf{1 d}$ only, $\mathrm{O}_{2}$ directly reacted with an intermediate to yield benzaldehyde. This was confirmed by carrying out a reaction with ${ }^{18} \mathrm{O}_{2}$ that yielded $\mathrm{PhCH}^{18} \mathrm{O}$.

Since it is known, as discussed above, that the reduced polyoxometalate, that is, $\mathrm{H}_{7} \mathrm{PV}^{\mathrm{IV}}{ }_{2} \mathrm{Mo}_{10} \mathrm{O}_{40}$, can be oxidized to $\mathrm{H}_{5} \mathrm{PV}_{2}{ }_{2} \mathrm{Mo}_{10} \mathrm{O}_{40}$ with $\mathrm{O}_{2}$, catalytic reactions were carried out as summarized in Table 1 . As seen in Table 1 , the reaction products were identical to those obtained in the stoichiometric

\section{Table 1. Aerobic Catalytic C-C Bond Coupling ${ }^{a}$}

$\begin{array}{cccc}\text { substrate } & \text { product } & \text { yield, mol \% } & \text { TON } \\ \text { 1a }(\mathrm{R}=\mathrm{H}) & 100 \% \text { ethane } & 61 & 35 \\ \text { 1b }(\mathrm{R}=\mathrm{Me}) & 100 \% n \text {-butane } & 64 & 37 \\ \text { 1c }(\mathrm{R}=\mathrm{Et}) & 100 \% n \text {-hexane } & 66 & 38 \\ \text { 1c }(\mathrm{R}=\mathrm{Et})^{b} & 100 \% n \text {-hexane } & 100 & 58 \\ \text { 1d }(\mathrm{R}=\mathrm{Ph}) & 89 \% \mathrm{PhCHO}, 11 \% \mathrm{Bz}-\mathrm{Bz} & 64 & 37\end{array}$

${ }^{a}$ Reaction conditions: $150 \mu \mathrm{mol}$ of $\mathbf{1 a}-\mathbf{d}, 2.6 \mu \mathrm{mol}$ of $\mathrm{H}_{5} \mathrm{PV}_{2} \mathrm{Mo}_{10} \mathrm{O}_{40}$, $15 \mathrm{~mL}$ of $n$-butyronitrile, 5 bar of $\mathrm{O}_{2}, 24 \mathrm{~h}, 60{ }^{\circ} \mathrm{C} .{ }^{b} 4 \mu \mathrm{mol}$ of $\mathrm{H}_{2} \mathrm{SO}_{4}$ added, $12 \mathrm{~h}$. reactions under $\mathrm{O}_{2}$. Furthermore, the yields and turnover numbers were very similar for all substrates, suggesting that in these reactions the rate-determining step for the catalytic reaction is the reoxidation of $\mathrm{H}_{7} \mathrm{PV}^{\mathrm{IV}}{ }_{2} \mathrm{Mo}_{10} \mathrm{O}_{40}$ with $\mathrm{O}_{2}$. Note that since in the oxidative reductive elimination process no protons are formed, their addition considerably improves the efficiency of the reoxidation reaction in the catalytic cycle (third entry); see also Scheme $1^{11}$

After demonstrating selective aerobic catalytic $\mathrm{C}-\mathrm{C}$ bond coupling, we turned our attention to the reaction mechanism and the identification of the apparent reaction intermediate, the blue precipitate. Given that $\mathrm{H}_{5} \mathrm{PV}_{2} \mathrm{Mo}_{10} \mathrm{O}_{40}$ reacts with 1 to create a more electron-poor metal center via electron transfer, two realistic reaction mechanisms can be contemplated: (i) Co-alkyl bond homolysis and (ii) direct reductive elimination (Scheme 2).

Scheme 2. Pathways for $\mathrm{C}-\mathrm{C}$ Bond Coupling of 1 with $\mathrm{H}_{5} \mathrm{PV}_{2} \mathrm{Mo}_{10} \mathrm{O}_{40}$

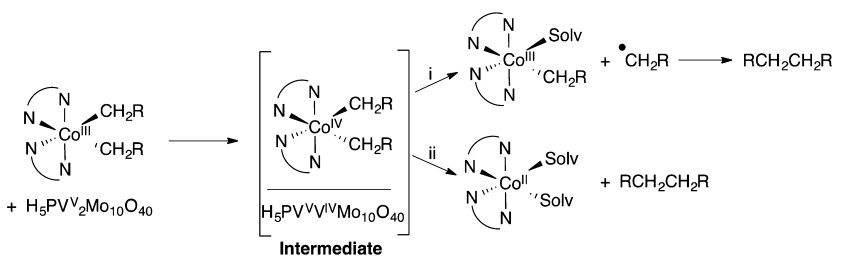

The Co-alkyl bond homolysis can be excluded as such a pathway and would likely yield various alkane isomers because one could expect stabilization of secondary carbon radicals versus primary ones. Thus, for alkyl $=n$-propyl, 2,3dimethylbutane would be a more likely product compared to the $n$-hexane. The formation of propane would also be possible in such a case by a hydrogen-atom-transfer step. In addition, a crossover experiment where a 1:1 ratio of $\mathrm{RCH}_{2}=$ Et and $n-\mathrm{Pr}$ were used as substrates, only $n$-butane and $n$-hexane were formed with no pentane product whatsoever. Disproportionation (not shown) was the likely pathway for oxidative $\mathrm{C}-\mathrm{C}$ bond coupling from square planar $\mathrm{Pd}(\mathrm{II})$ and $\mathrm{Pt}(\mathrm{II})$ complex$\mathrm{es}^{2 \mathrm{a}, 12}$ however, this seems very unlikely in this case because this would require the formation of a heptacoordinate $\mathrm{Co}(\mathrm{V})$ complex and a $\mathrm{Co}(\mathrm{III})$ complex from an initially formed $\mathrm{Co}(\mathrm{IV})$ intermediate. Furthermore, a crossover experiment as mentioned above would be expected to yield butane, pentane, and hexane in a 1:2:1 ratio. Thus, the results would appear to support a direct reductive elimination pathway as the most reasonable option to explain the high selectivity of the reaction.

A qualitative determination of the blue intermediate species obtained from an equimolar mixture of $1 \mathrm{c}$ and $\mathrm{H}_{5} \mathrm{PV}_{2} \mathrm{Mo}_{10} \mathrm{O}_{40}$ as portrayed in Scheme 2 can be obtained by low-temperature X-band EPR spectroscopy, Figure 2. One can discern two peaks: the typical anisotropic spectrum at $g=\sim 2.1$ for a vanadium(IV) species associated with the one-electron reduced polyoxometalate $^{13}$ and a peak at $g=\sim 4.3$ that we associate with a small amount of a $S=3 / 2 \mathrm{Co}$ (II) species that is formed in the reaction (see below). ${ }^{14} \mathrm{~A}$ peak assignable to $\mathrm{Co}(\mathrm{IV})$ is not apparent. ${ }^{14}$ Under conditions where the intermediate is let to react in the solid state, the peak associated with the $S=3 / 2$ $\mathrm{Co}$ (II) species is more significant (Figure S15).

Despite the obvious redox reaction between $1 \mathrm{c}$ and $\mathrm{H}_{5} \mathrm{PV}_{2} \mathrm{Mo}_{10} \mathrm{O}_{40}$ and the formation of $\mathrm{V}(\mathrm{IV})$ as shown by $\mathrm{EPR}$, and because the peak associable to $\mathrm{Co}(\mathrm{IV})$ was not 


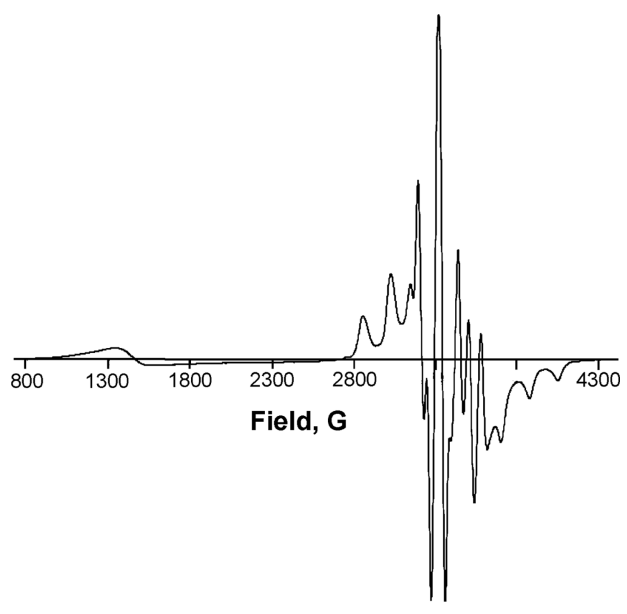

Figure 2. X-band EPR spectrum of the intermediate species.

observed, we turned to XPS measurements to obtain further information and to quantitatively decipher the cobalt and vanadium species as a function of their oxidation states. Thus, 1c and $\mathrm{H}_{5} \mathrm{PV}_{2} \mathrm{Mo}_{10} \mathrm{O}_{40}$ were reacted in a $1: 1$ ratio. The blue precipitate that was formed was immediately vacuum filtered, dried under high vacuum, transferred to a carbon tape, and promptly taken to the spectrometer to minimize air exposure of the sample. Compounds $1 \mathrm{c}$ and $\left[\mathrm{Co}^{\mathrm{II}}(\mathrm{bpy})_{2}\left(\mathrm{CH}_{3} \mathrm{CN}\right)_{2}\right] \mathrm{Cl}_{2}$ were used as references for cobalt(III) and cobalt(II), ${ }^{15}$ respectively. $\mathrm{H}_{5} \mathrm{PV}_{2} \mathrm{Mo}_{10} \mathrm{O}_{40}$ was used as a reference for vanadium $(\mathrm{V})$. The $\mathrm{X}$-ray photoelectron spectroscopy (XPS) Co $2 \mathrm{p}_{3 / 2}$ line of the intermediate and the control compounds for $\mathrm{Co}(\mathrm{II})$ and $\mathrm{Co}(\mathrm{III})$ are presented in Figure 3, left. The first

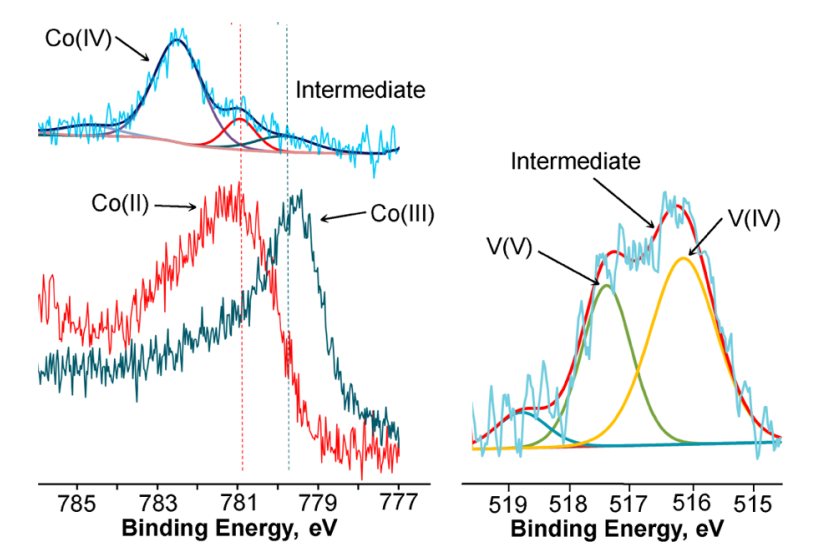

Figure 3. X-ray photoelectron spectra of the reaction intermediate, 1c, and reference compound, $\left[(\mathrm{Solv})_{2} \mathrm{Co}^{\mathrm{II}}(\mathrm{bpy})_{2}\right] \mathrm{Cl}_{2}$. Left: the Co $2 \mathrm{p}_{3 / 2}$ spectral window. Right: the $\mathrm{V} 2 \mathrm{p}_{3 / 2}$ line.

point of note is that, unusually, the $\mathrm{Co}$ (II) compound has a higher binding energy, $780.9 \mathrm{eV}$, than the $\mathrm{Co}(\mathrm{III})$ compound, $779.7 \mathrm{eV}$, which is opposite to the general trend of chemical shifts in XPS; the general trend is the higher the oxidation state, the higher the binding energy. This phenomenon has already been reported and explained by the presence of strong electron interactions: the occupied $\mathrm{d}_{\mathrm{z} 2}$ valence orbital in Co(II) increases the binding energy, ${ }^{16}$ while the absence of an electron in the valence orbital of $\mathrm{Co}$ (III) leads to a lower binding energy, despite the higher oxidation state. Clearly, the intermediate has a significantly higher binding energy, 782.5 $\mathrm{eV}$, see Figure 3, than the two reference samples. It is assigned to a $\mathrm{Co}$ (IV) metal center. Notably, additional $\mathrm{Co}$ (II) and $\mathrm{Co}$ (III) are found as well in this case, and this finding is discussed below.

In Figure 3, right, we present the XPS V 2 $\mathrm{p}_{3 / 2}$ line of the intermediate. As would be expected for a one-electron transfer process, the reaction of $1 \mathrm{c}$ and $\mathrm{H}_{5} \mathrm{PV}_{2}{ }_{2} \mathrm{Mo}_{10} \mathrm{O}_{40}$ should yield an intermediate containing $\left[\mathrm{PV}^{\mathrm{IV}} \mathrm{V}^{\mathrm{V}} \mathrm{Mo}_{10} \mathrm{O}_{40}\right]^{6-}$ that would have an equimolar amount of $\mathrm{V}(\mathrm{IV})$ and $\mathrm{V}(\mathrm{V})$. Figure 3 suggests that this is approximately though not exactly correct. The measured higher amount of $\mathrm{V}(\mathrm{IV})$ versus $\mathrm{V}(\mathrm{V})$ and the small amounts of $\mathrm{Co}$ (II) and even $\mathrm{Co}(\mathrm{III})$ can be attributed to impurities in the intermediate, which is due to its further reaction under the vacuum conditions and low-flux X-ray irradiation to yield $n$-hexane and a $\mathrm{Co}$ (II) compound by reductive elimination (Scheme 2). The latter can then be oxidized by the polyoxometalate to yield a Co(III) compound and more $\mathrm{V}(\mathrm{IV})$ species, thus explaining all the experimental XPS results.

\section{CONCLUSION}

An aerobic oxidative catalytic $\mathrm{C}-\mathrm{C}$ bond coupling reaction of an octahedral dialkyl-cobalt(III) complex, $\left[\left(\mathrm{RCH}_{2}\right)_{2} \mathrm{Co}^{\mathrm{III}}(\mathrm{bpy})_{2}\right]^{+}$, yielded the head-to-head product only, for example, $n$-hexane from $\mathrm{R}=\mathrm{Et}$. The reaction was shown to take place by using $\mathrm{H}_{5} \mathrm{PV}_{2}{ }_{2} \mathrm{Mo}_{10} \mathrm{O}_{40}$ as an electrontransfer catalyst, forming a $\left[\left(\mathrm{RCH}_{2}\right)_{2} \mathrm{Co}^{\mathrm{IV}}(\mathrm{bpy})_{2}\right]^{2+}-$ $\mathrm{H}_{5} \mathrm{PV}^{\mathrm{IV}} \mathrm{V}^{\mathrm{V}} \mathrm{Mo}_{10} \mathrm{O}_{40}$ intermediate at room temperature. By heating to $50{ }^{\circ} \mathrm{C}$, the $\mathrm{C}-\mathrm{C}$ bond coupling takes place through a reductive elimination step. For $\mathrm{RCH}_{2}=\mathrm{Bz}$, oxygenation also occurs in significant amounts in a kinetically competitive reaction. The working hypothesis is that $\mathrm{O}_{2}$ can react with the reduced polyoxometalate in the intermediate to yield a superoxide $\left(\mathrm{V}^{\mathrm{V}}-\mathrm{OO} \cdot\right)$, which leads to oxygenation and formation of the aldehyde. Interestingly, the EPR spectrum indicates that the $\mathrm{Co}$ (II) species formed is high spin, $\mathrm{S}=3 / 2$. This species is reoxidized to yield a diamagnetic $\mathrm{Co}$ (III) species and $\mathrm{H}_{5} \mathrm{PV}^{\mathrm{IV}}{ }_{2} \mathrm{Mo}_{10} \mathrm{O}_{40}$. Since the latter is easily oxidized in the presence of protons and $\mathrm{O}_{2}$ as terminal oxidant, catalytic turnover is observed under aerobic conditions, a novel finding in this area where the use of one- and two-electron stoichiometric oxidants is the norm. Future research will be focused on combining alkane activation with oxidative $\mathrm{C}-\mathrm{C}$ bond coupling as described.

\section{EXPERIMENTAL SECTION}

Synthesis of Complexes $1 \mathbf{a}-\mathbf{d}$. An orange deaerated solution of $0.78 \mathrm{~g}(5 \mathrm{mmol})$ of 2,2-bipyridine and $0.60 \mathrm{~g}(2.5$ $\mathrm{mmol})$ of $\mathrm{CoCl}_{2} \cdot 6 \mathrm{H}_{2} \mathrm{O}$ in $50 \mathrm{~mL}$ of methanol was prepared, and then the corresponding alkyl halide $(7.5 \mathrm{mmol} \mathrm{RI;} \mathrm{R}=\mathrm{Me}$ $\mathrm{Et}$, $\mathrm{n}$-Pr or $5.0 \mathrm{mmol} \mathrm{BzCl}$ ) was added to the solution under a slight positive pressure of $\mathrm{Ar} . \mathrm{NaBH}_{4}(0.2 \mathrm{~g}, 5 \mathrm{mmol})$ was added under vigorous stirring in small portions during a period of 40 min. After every addition of $\mathrm{NaBH}_{4}$, a blue $\mathrm{Co}$ (I) intermediate was formed. The next portion was added only after the blue color disappeared. After a few portions, the solution slowly became dark red. Note that an excess of $\mathrm{NaBH}_{4}$ needs to be avoided. The red solution was treated with $0.3 \mathrm{~g}$ of $\mathrm{NaClO}_{4}$ dissolved in $10 \mathrm{~mL}$ of water followed by evaporation to $15 \mathrm{~mL}$. Addition of $30 \mathrm{~mL}$ of cold $\mathrm{H}_{2} \mathrm{O}$ yielded a precipitate that was collected by centrifugation. The precipitate was washed with cold water until the wash was almost colorless. Water was removed by lyophilization, and the products were 
stored at $-80{ }^{\circ} \mathrm{C} .{ }^{1} \mathrm{H}$ NMR and ${ }^{13} \mathrm{C}$ NMR were recorded on Bruker Avance 300 and $500 \mathrm{MHz}$ spectrometers at $298 \mathrm{~K}$ and referenced to solvent shift. The NMR and HR-MS spectra of $\mathbf{1 a}-\mathbf{d}$, and their analysis can be found in the Supporting Information.

Synthesis of Complex 1e. An orange deaerated solution of $0.78 \mathrm{~g}(5.0 \mathrm{mmol})$ of 2,2-bipyridine and $0.60 \mathrm{~g}(2.5 \mathrm{mmol})$ of $\mathrm{CoCl}_{2} \cdot 6 \mathrm{H}_{2} \mathrm{O}$ in $30 \mathrm{~mL}$ of methanol and $20 \mathrm{~mL}$ of dimethoxy ethane was prepared, and then $0.2 \mathrm{~g}(0.625 \mathrm{mmol})$ of $1,4-$ diidobutane was added. The solution was deaerated for $15 \mathrm{~min}$ with $\mathrm{Ar}$, and then $2.5 \mathrm{mmol}$ of $\mathrm{NaBH}_{4}$ was added as described above and left to react for an additional $20 \mathrm{~min}$. Next, $0.3 \mathrm{~g}(2.5$ $\mathrm{mmol}$ ) of the product was isolated as described above. Note that the use of $1.25 \mathrm{mmol}$ of 1,4-diidobutane yielded a dialkyl complex with two iodo-butane ligands and not the metallocycle. This compound also underwent $\mathrm{C}-\mathrm{C}$ coupling to yield 1,8 diiodooctane.

X-ray Crystallography. Samples $(10 \mathrm{mg})$ were dissolved in $1 \mathrm{~mL}$ of $\mathrm{CH}_{3} \mathrm{CN}$ in a $2 \mathrm{~mL}$ vial. The open vial was inserted in a $20 \mathrm{~mL}$ vial with $3 \mathrm{~mL}$ of diethyl ether. The bigger vial was tightly closed and left for 2 weeks at $4{ }^{\circ} \mathrm{C}$. Single-crystal X-ray data were collected on a Bruker APEX-II Kappa CCD or Rigaku XtaLab PRO equipped with PILATUS 200 diffractometer with Mo $\mathrm{K} \alpha(\lambda=0.71073 \mathrm{~nm})$ radiation and graphite monochromator. Measurements were performed at $100 \mathrm{~K}$ under liquid $\mathrm{N}_{2}$ to achieve better -quality data. The data were processed using Bruker Apex 2 suite for complex $1 \mathbf{c}$ and $\mathbf{1 d}$, and CrysAlisPro $1.171 .39 .4 \mathrm{c}$ for 1e. Structures were solved by direct methods with SHELXS or SHELXT. Full-matrix least-squares refinement was based on $F^{2}$ with SHELXL-2014. The crystallographic data are presented in Table S1.

X-ray Photoelectron Spectroscopy. Compound 1c and $\mathrm{H}_{5} \mathrm{PV}_{2} \mathrm{Mo}_{10} \mathrm{O}_{40}$ were reacted at a 1:1 ratio. The blue precipitate that was formed was immediately vacuum filtered, dried under high vacuum, transferred to a carbon tape, and promptly taken to the spectrometer to minimize oxygen exposure of the sample. Measurements were performed in a Kratos AXIS-Ultra DLD spectrometer at a base pressure of $10^{-9}$ Torr, using monochromatic $\mathrm{Al} \mathrm{K} \alpha$ source at a highly reduced power, up to $15 \mathrm{~W}$ at the most. Charge compensation by an electron flood gun was needed in all measurements of these powders. Given the large spot-dependent charging variations and small yet important binding energy chemical shifts in the organic species, we used the two leading $C$ 1s lines of the bipyridine ligands for energy-scale calibration (cross checked with the bipyridine nitrogen and with the Mo $3 \mathrm{~d}$ of the polyoxometalate signal). This referencing procedure reduced the uncertainty in binding energies to values much smaller than the differences observed in the Co line. Particular care was taken in our procedures because sample degradation occurs under X-ray irradiation; as such, we used extremely low fluxes and repeated scans in order to follow those processes and eventually extract the data under minimally damaging conditions. ${ }^{17}$

EPR Spectroscopy. Compound $1 \mathrm{c}$ and $\mathrm{H}_{5} \mathrm{PV}_{2} \mathrm{Mo}_{10} \mathrm{O}_{40}$ were reacted at a 1:1 ratio, the blue precipitate that was formed was immediately transferred into an EPR capillary tube and analyzed on the spot. X-band EPR spectra were recorded on a Bruker ELEXSYS 500 spectrometer equipped with a Bruker ER4122SHQE resonator at $20 \mathrm{~K}$ with microwave power of $20 \mathrm{~mW}, 0.1 \mathrm{mT}$ modulation amplitude and $100 \mathrm{kHz}$ modulation frequency.

Carbon-Carbon Coupling Reactions. Stoichiometric reactions: 1a-e $(30 \mu \mathrm{mol})$ and $30 \mu \mathrm{mol}(69 \mathrm{mg})$ of
$\mathrm{H}_{5} \mathrm{PV}_{2} \mathrm{Mo}_{10} \mathrm{O}_{40} \cdot 32 \mathrm{H}_{2} \mathrm{O}^{18}$ each in $3 \mathrm{~mL}$ of $n$-butyronitrile were mixed in an Ace glass pressure tube and then frozen, degassed, and filled with $1.5 \mathrm{~atm}$ of $\mathrm{Ar}$ or $\mathrm{O}_{2}$ The mixture was stirred at $50{ }^{\circ} \mathrm{C}$ for $3 \mathrm{~h}$, cooled to $\sim 0{ }^{\circ} \mathrm{C}$, and analyzed by gas chromatography. Catalytic reactions: $1 \mathrm{a}-\mathbf{d}(150 \mu \mathrm{mol})$ were reacted with $2.6 \mu \mathrm{mol}(6 \mathrm{mg})$ of $\mathrm{H}_{5} \mathrm{PV}_{2} \mathrm{Mo}_{10} \mathrm{O}_{40} \cdot 32 \mathrm{H}_{2} \mathrm{O}$ in 15 $\mathrm{mL}$ of $n$-butyronitrile for $24 \mathrm{~h}$ at $60{ }^{\circ} \mathrm{C}$ under 5 bar $\mathrm{O}_{2}$. Gas phases were analyzed by GC-TCD equipped with a $2 \mathrm{~m}, 0.53$ $\mu \mathrm{m}$ i.d. Restek ShinCarbon ST 80/100 column and quantified using standards. Liquids were qualitatively analyzed GC-MS and quantified by GC-FID for quantitative analysis using a Restek 5\% phenyl methylsilicone $0.32 \mathrm{~mm}$ i.d., $0.25 \mathrm{~mm}$ coating, $30 \mathrm{~m}$ column with $\mathrm{He}$ as carrier gas.

\section{ASSOCIATED CONTENT}

\section{Supporting Information}

The Supporting Information is available free of charge on the ACS Publications website at DOI: 10.1021/acscatal.7b00461.

Crystallographic data, additional NMR data, ORTEP drawing, high-resolution ESI-MS, X-band EPR spectrum (PDF)

X-ray data (CIF)

X-ray data (CIF)

$\mathrm{X}$-ray data (CIF)

\section{AUTHOR INFORMATION}

\section{Corresponding Author}

*E-mail: Ronny.Neumann@weizmann.ac.il.

ORCID

Ronny Neumann: 0000-0002-5530-1287

Present Address

$\S$ (J.N.R.) Department of Chemistry, California Institute of Technology, Pasadena, CA 91125, United States. E-mail: jrosenbe@caltech.edu

\section{Author Contributions}

The manuscript was written through contributions of all authors and they have given their approval to the final version of the manuscript.

\section{Notes}

The authors declare no competing financial interest.

\section{ACKNOWLEDGMENTS}

This research was supported by the Israel Science Foundation (grant no. 2046/14). Bidyut B. Sarma is thanked for his assistance. R.N. is the Rebecca and Israel Sieff Professor of Organic Chemistry.

\section{REFERENCES}

(1) Tsou, T. T.; Kochi, J. K. J. Am. Chem. Soc. 1978, 100, 1634-1635. (2) (a) Lanci, M. P.; Remy, M. S.; Kaminsky, W.; Mayer, J. M.; Sanford, M. S. J. Am. Chem. Soc. 2009, 131, 15618-15620. (b) Lanci, M. P.; Remy, M. S.; Lao, D. B.; Sanford, M. S.; Mayer, J. M. Organometallics 2011, 30, 3704-3707. (c) Khusnutdinova, J. R.; Rath, N. R.; Mirica, L. M. J. Am. Chem. Soc. 2012, 134, 2414-2422. (d) Byers, P. K.; Canty, A. J.; Skelton, B. W.; White, A. H. J. J. Chem. Soc., Chem. Commun. 1986, 0, 1722-1724. (e) Byers, P. K.; Canty, A. J.; Crespo, M.; Puddephatt, R. J.; Scott, J. D. Organometallics 1988, 7, 1363-1367. (f) Duecker-Benfer, C.; van Eldik, R.; Canty, A. J. Organometallics 1994, 13, 2412-2414. (g) Canty, A. J. Dalton Trans. 2009, 10409-10417. (h) Khusnutdinova, J. R.; Qu, F.; Zhang, Y.; Rath, N. P.; Mirica, L. M. Organometallics 2012, 31, 4627-4630. 
(i) Tang, F.; Zhang, Y.; Rath, N. P.; Mirica, L. M. Organometallics 2012, 31, 6690-6696.

(3) (a) Lotz, M. D.; Remy, M. S.; Lao, D. B.; Ariafard, A.; Yates, B. F.; Canty, A. J.; Mayer, J. M.; Sanford, M. S. J. Am. Chem. Soc. 2014, 136, 8237-8242. (b) Xu, H.; Diccianni, J. B.; Katigbak, J.; Hu, C.; Zhang, Y.; Diao, T. J. Am. Chem. Soc. 2016, 138, 4779-4786.

(4) Sato, M.; Mogi, E.; Kumakura, S. Organometallics 1995, 14, 3157-3159.

(5) (a) Kraatz, H. B.; van der Boom, M. E.; Ben-David, Y.; Milstein, D. Isr. J. Chem. 2001, 41, 163-172. (b) MacLeod, K. C.; Patrick, B. O.; Smith, K. M. Organometallics 2012, 31, 6681-6689.

(6) Albéniz, A.; Espinet, P.; Martín-Ruiz, B. Chem. - Eur. J. 2001, 7, 2481-2489.

(7) Ball, N. D.; Kampf, J. W.; Sanford, M. S. J. Am. Chem. Soc. 2010, 132, 2878-2879.

(8) (a) Neumann, R. Inorg. Chem. 2010, 49, 3594-3601. (b) Neumann, R.; Khenkin, A. M. Chem. Commun. 2006, 2529-2538.

(9) Khenkin, A. M.; Efremenko, I.; Martin, J. M. L.; Neumann, R. J. Am. Chem. Soc. 2013, 135, 19304-19310.

(10) Mestroni, G.; Camus, A.; Mestroni, E. J. Organomet. Chem. 1970, 24, 775-781.

(11) In a reaction cycle including alkane activation, the needed protons would come from the activation step.

(12) Johansson, L.; Ryan, O. B.; Romming, C.; Tilset, M. Organometallics 1998, 17, 3957-3966.

(13) (a) Kaminker, I.; Goldberg, H.; Neumann, R.; Goldfarb, D. Chem. - Eur. J. 2010, 16, 10014-10020. (b) Goldberg, H.; Kaminker, I.; Goldfarb, D.; Neumann, R. Inorg. Chem. 2009, 48, 7947-7952.

(14) (a) McAlpin, J. G.; Surendranath, Y.; Dinca, M.; Stich, T. A.; Stoian, S. A.; Casey, W. H.; Nocera, D. G.; Britt, R. D. J. Am. Chem. Soc. 2010, 132, 6882-6883. (b) Jiménez, H. R.; Salgado, J.; Moratal, J. M.; Morgenstern-Badarau, I. Inorg. Chem. 1996, 35, 2737-2741.

(15) Sobkowiak, A.; Sawyer, D. T. J. Am. Chem. Soc. 1991, 113, 9520-9523.

(16) (a) Burger, K.; Furlani, C.; Mattogno, G. J. Electron Spectrosc. Relat. Phenom. 1980, 21, 249-256. (b) Ivanova, T.; Naumkin, A.; Sidorov, A.; Eremenko, I.; Kiskin, M. J. Electron Spectrosc. Relat. Phenom. 2007, 156-158, 200-203.

(17) Frydman, E.; Cohen, H.; Maoz, R.; Sagiv, J. Langmuir 1997, 13, 5089-5106.

(18) Tsigdinos, G. A.; Hallada, C. J. Inorg. Chem. 1968, 7, 437-441. 